\title{
腎移植患者の長期予後と社会復帰の現況
}

\author{
岡 隆 宏 安村 忠樹相川一郎 \\ 京都府立医科大学第 2 外科 \\ (昭和 62 年 9 月 28 日受付)
}

key words: 腎移植, 10 年成績, 合併症, 社会復帰

〈要旨〉

腎移植後の長期予後と社会復帰の現況を検討する目的で, 京都府立医科大学第二外科で腎移植を施行し10 年以上経 過した 72 例を対象として, 生存率, 生着率, 及び 10 年生着にかかわる諸因子, 合併症について検討し, 同時に移植 後 1 年以上生着した症例 54 例を対象として, アンケート調査による検討を行った. 腎移植後, 10 年生存した症例は 72 例中 57 例, 生着したものは 39 例であり, 実例生存率は $79 \%$, 生着率は $54 \%$ であった。 さらに 10 年以上生着した症 例では, その後の死亡例はなく, 3 例が慢性拒絶反応で血液透析にもどったため, 10 年以降の 5 年生着率は $87 \%$ とな る。10 年以上の生着に影響を及ぼす因子としては, 術前ではドナーの年齢が 50 歳未満であること, 術後では慢性拒絶 反応の出現であった. 10 年生着症例に, 特に重篤な合併症は出現しないが, 肝機能障害が問題となる. 腎移植後の社 会復帰の状況は, 完全社会復帰率が $89 \%$ ときわめて良好であり, 一日の労働時間 8.5 時間, 一週間の休日数 1.2 日と, 健康人とほとんど変わりのない社会生活, 家庭生活を送っており, 患者の健康感でも $90 \%$ 以上の患者が, 血液透析の 頃よりも健康になったと感じていた。このように腎移植は慢性腎不全に対するきわめて有利な治療法といえる。

\section{Long-term prognosis and rehabilitation of kidney transplant recipients}

Takahiro Oka, M. D., Tadaki Yasumura, M. D., Ichiro Aikawa, M. D.

Second Department of Surgery, Kyoto Prefectural University of Medicine

Seventy two renal transplant recipients who had received living related kidney transplants 10 or more years previously were studied to determine the outcome and the major factors responsible for the improved graft survival. Of 72 cases, 57 patients and 39 grafts survived for more than 10 years. So actual patient and graft survivals were $79 \%$ and $54 \%$, respectively, at 10 years. A preoperative contributing factor for prolonged graft survival was a donor age of less than 50 years. Post-operatively chronic rejection was the major cause of later graft loss. Patients with grafts surviving over 10 years have few life-threatening complications. However, 6 patients developed liver dysfunction. Some of these were accompanied with liver cirrhosis or esophageal varices.

To evaluate the degree of patient rehabilitation, questionnaires were administered to 154 patients with grafts functioning more than one year. Full-time employment, housework and schooling was attained by 137 of the 154 patients $(89 \%)$ following transplantation. The mean working hours was $8.5 \pm 1.4$ hours a day and the mean holiday was $1.2 \pm 0.4$ days a week. More than $90 \%$ of patients considered that health and activity similar to the pre-illness level was achieved by kidney transplantation.

Hence most recipients of kidney transplants who maintain stable renal functions can expect an almost normal level of physical activity and enjoy their life of the pre-illness level of activity.

岡隆 宏 京都府立医科大学第 2 外科

于 602 京都市上京区河原町通広小路上儿梶井町 $465(075-251-5111)$
はじめに

慢性腎不全に対する治療に, 血液浄化療法と腎移植が あるが,これらの最終目標はいずれも, 患者の身体的条 件を長期間良好に保ち, さらによりよい社会復帰を得さ せるということにある。近年の血液浄化療法の普及進歩 


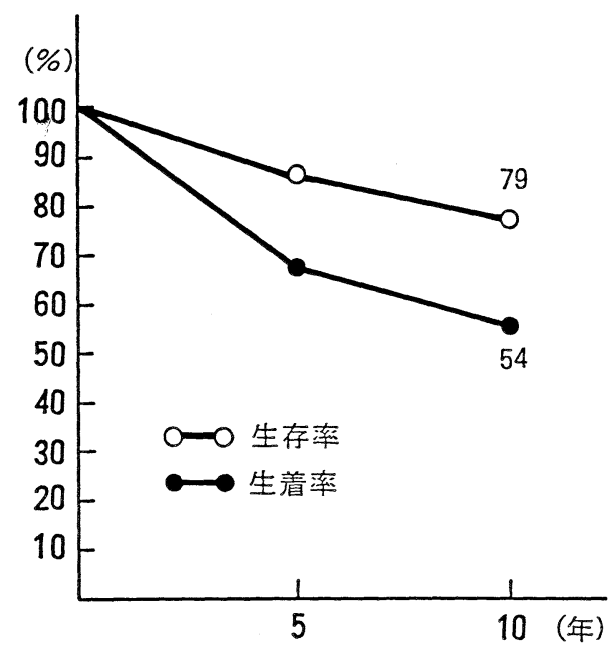

図 1 生体腎移植症例の 10 年生存率生着率

により，この治療で 10 年以上延命している患者は増加 し，制限つきではあるが，彼らが十分社会復帰できるよ うになった。一方，腎移植は血液浄化療法では補えない 長所を持つため，これに成功すれば，種々の制限から解 放され，より高い quality of life が約束される。またこ れが慢性腎不全に対する治療として腎移植に課せられた 役割といえる。

腎移植の有効性を評価す場合，腎移植の長期の成功率 と移植後の社会復帰が重要な問題点であり，また透析医 の立場から見ればこの二点が重大な関心事でもあろう。 そこで本稿では，腎移植後の社会復帰の現況を調査する と共に, 移植後 10 年以上経過した症例について検討し た.

\section{対象症例}

京都府立医科大学第 2 外科では昭和 45 年 4 月より現 在まで 296 例の腎移植を施行したが，これらの症例を対 象として，以下の検討をおこなった。腎移植後 10 年以上 経過した症例の検討では, 昭和 45 年 4 月から昭和 52 年 6 月までに腎移植を受けた 72 例を対象とした。これらは 全例血縁者間の生体腎移植で，ドナーとの組織適合度は identical sibling は 8 例，残る 64 例は one haploidentical combination であった。免疫抑制療法は全例アザチ オプリンとプレドニンの併用療法を用いている。

腎移植後の社会復帰状況に関する調査は,昭和 45 年 4 月から昭和 60 年 11 月までに移植腎が生着している 154 例（生体腎移植：142 例，死体腎移植 12 例）にアンケー トを配布し，回収し得た 127 例（回収率 82.5\%）の回答 をもとに検討した。アンケートを回収した 127 例中 116 例が生体腎移植であり，11 例が死体腎移植である。また 腎移植後の免疫抑制療法は，アザチォプリンとプレドニ

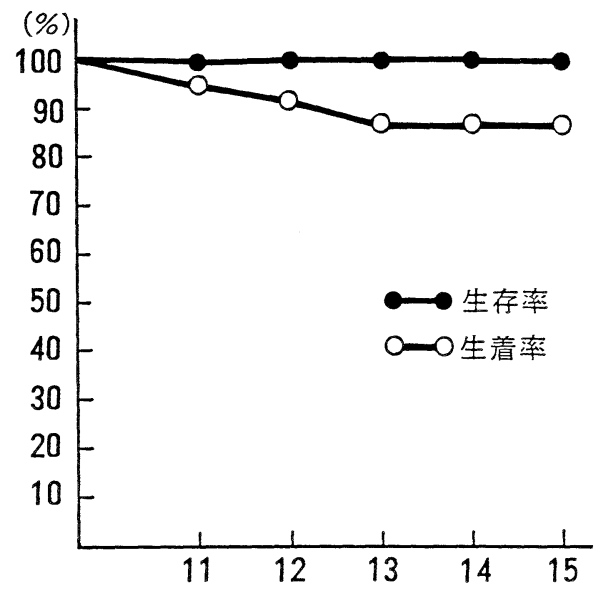

(年)

図 210 年以上生着した症例に扔ける 10 年以降 の生存率と生着率

表 110 年以上の生着に関わる諸因子
術前の因子

1.レシピエントの年齢*

2 . 透析期間*

3. 原疾患の種類*

4. 組織適合度の相違*

5. HBsAg の有無*

6 . 術前輸血の有無*

7 . 術前輸血量の差*

8. ドナーの年齢 *
術後の因子

1. ATN の有無*

2. 急性拒絶反応の有無

3 . 感染症の有無 $*$

4. 慢性拒絶反応の有無 ${ }^{*}$

*関連なし

$\circledast$ 関連あり
ンの併用療法を行ったものは 79 例, シクロスポリンとプ レドニンの併用療法を行ったものは 48 例であった。

\section{結果}

1. 腎移植後 10 年以上生着した症例の検討

腎移植では合併症を持たずに，より長期間の移植腎の 生着が得られるか否かが，大きな問題となる。そこで 10 年間以上の生着をもたらした要因と 10 年以上生着した 症例の持つ問題点を検討した。

1) 腎移植術後の 10 年生存, 生着率

生体腎移植症例に打ける 10 年累積生存, 生着率を図 1 に示した. 10 年生存率は $79 \%$, 生着率は $54 \%$ であり, 10 年以上経過した 72 例中, 生存しているものは 57 例, 移 植腎が生着しているものは 39 例である。また 10 年以上 生着した症例に打ける, 10 年以降の生存, 生着率(図 2 ) を見ると, 生存率では 15 年まで $100 \%$ で, 生着率では 87\%で，3 例が graft loss に括ちいった。この原因は 3 例とも慢性拒絶反応で, 2 例は現在血液透析中であるが, 残る 1 例はその後死体腎移植をうけ，現在良好は腎機能 を保ち社会復帰している。

2） 10 年以上の生着に関わる諸因子 
表 210 年以上生着者の合併症

\begin{tabular}{l|c}
\hline HBs 抗原キャリアー & 11 例 \\
肝障害 & 6 \\
\multicolumn{1}{c}{ (肝硬変 } & 3 \\
食道静脈瘤 & 2 \\
無菌性骨壊死 & 4 \\
慢性拒絶反応 & 2 \\
全盲 (術前より) & 2 \\
\hline
\end{tabular}

表 3 腎移植後の患者の就業している 職種と社会復帰率

\begin{tabular}{l|l|c}
\hline \multicolumn{1}{c|}{ 職 種 } & 症例数 & 比 率 \\
\hline 公務員 & 13 例 & $8.5 \%$ \\
会社員 & 55 & 35.7 \\
自掌 & 33 & 21.4 \\
主 婦 & 23 & 14.9 \\
学 生 & 13 & 8.5 \\
臨時雇, パートタイマー & 4 & 2.6 \\
家事手伝い & 7 & 4.5 \\
失業中 & 6 & 3.9 \\
\hline
\end{tabular}

社会復帰率 $96.1 \%(148 / 154)$

完全社会復帰率 $89.0 \%(137 / 154)$

表 4 腎移植後の患者の就労状況 (公務員, 会社員, 自営業, 80 例)

\begin{tabular}{l|c}
\hline 平均年齢 & $35.5 \pm 6.7$ 歳 \\
労働時間 (時間/日) & $8.5 \pm 1.4$ 時間 \\
休日数 (日/週) & $1.2 \pm 0.4$ 日 \\
仕事の程度 & \\
$\quad$ 健康時と同程度 & $51.2 \%$ \\
$\quad$ 自制している & 33.8 \\
$\quad$ 疲れ易いので制限 & 13.8 \\
$\quad$ 極端に制限 & 1.2 \\
$\quad$ 無回答 & 0 \\
\hline
\end{tabular}

10 年以上の生着に関わる諸因子を, 生着例, 非生着例 について比較検討した(表 1 )。術前の因子としては，レ シピエントの年齢，透析期間，原疾患の種類，組織適合 度, $\mathrm{HB}$ 抗原の有無, 輸血, ドナーの年齢などが上げら れるが，これらのうち関連が見られた因子はドナーの年 齢であり, 年齢 50 歳を境として, それ未満の者が有意に 良好な 10 年生着率を示した。一方, 術後の因子では, ATN, 急性拒絶反応, 感染症の有無などには関連はなく, 慢性拒絶反応が 10 年生着を妨げる大きな因子であった。

3 ）免疫抑制剂の投与量

慢性拒絶反応の発症には, 移植後の免疫抑制剂の投与 量が大きく影響すると考えられる. 10 年以上生着した症 例では 33 例がアザチオプリンとプレドニンの併用療法, 5 例がアザチオプリン, プレドニン，ミゾリビンの 3 剂 併用療法が行われていた。 また投与重はアザチオプリン

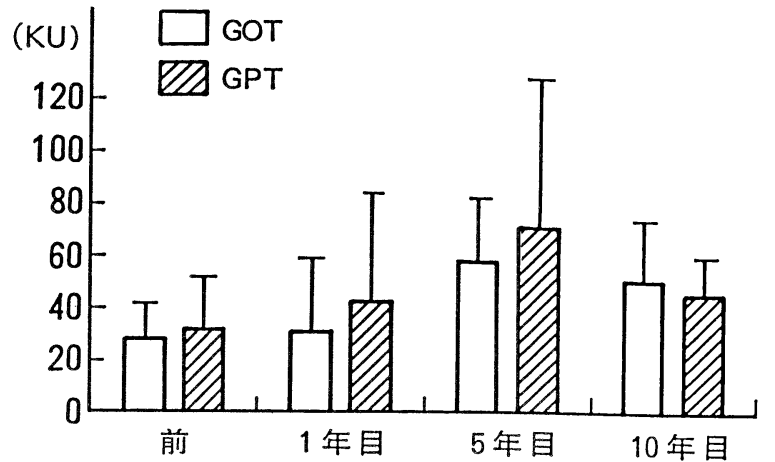

図 310 年以上生着者の肝機能障害例における 移植前後の肝機能

は 50-100 mg/日で, 平均 $100.6 \mathrm{mg} /$ 日, プレドニンは 2 . 5-10 mg/日で平均 $8.8 \mathrm{mg} /$ 日であった。

4) 10 年生着例における合併症

10 年以上生着した症例が, 現在持っている合併症を表 2 に示した。 慢性拒絶反応が 2 例に見られる他, HBs 抗 原キャリアー11 例, 肝機能障害 6 例, 無腐性骨壊死 4 例, 移植前からの全盲 2 例が認められた。これらのうち，と くに肝機能障害では (図 3 ) 術前異常を認めなかったが, 移植後 5 年目から GOT, GPT のみ異常高值をとった。 また 6 例中 2 例に食道静脈瘤を発症し, 硬化療法や脾臓 摘出などの手術がなされている.

2 . 腎移植後の社会復帰

対象症例 154 例が従事している職種を表 3 に示した。 公務員 $8.5 \%$, 会社員 $35.7 \%$, 自営業 $21.0 \%$ であり, 公 務員, 会社員などのいわゆるサラリーマンの比率は低 かった.アンケート調査施行時, 全体では 6 例が失業中 であったため, 社会復州率は $96.1 \%$ となるが, このうち 移植前後の合併症のため定職につけず,パートタイマー, 家事手伝いなどの仕事に従事している症例が 11 例あり, 従って完全社会復帰率は $89.0 \%$ となる。

1) 就労状況

公務員, 会社員, 自営業など定職に就いている 80 例の 就労状況（表 4 ）では, 労働時間は一日 8.5 時間, 休日 数は一週間 1.2 日であり, 仕事の程度でも健康時と同程 度 $51.2 \%$, 自制している $33.8 \%$ であり, 仕事を制限して いる患者は $15.0 \%$ にすぎなかった。

2 ）余㗇休日の評価と過ごし方

余暇や休日の活動度では, 全体の $85 \%$ が健康時と同程 度, あるいは血液透析中より活発と答え, 過ごし方につ いても家族と一緒に, 趣味スポーツなど，仕事といった 積極的な過ごし方が多く，なんとなくぶらぶらとか，疲 れるので体を休める, といった消極的な過ごし方の比率 は低かった。 
表 5 腎移植後の患者の休日余㗇の すごし方と評価

\begin{tabular}{l|c}
\hline 評 価 & \\
健康時と同程度 & $49.6 \%$ \\
血液透析中より活発 & 36.0 \\
血液透析中と同じ & 3.6 \\
血液透析中より悪い & 1.8 \\
無回答 & 9.0 \\
\hline すごし方 & \\
家族と一緒に楽しむ & 28.2 \\
趣味, スポーツなど & 27.2 \\
仕 事 & 12.5 \\
何となくぶらぶら & 14.7 \\
疲れるので体を休める & 17.4 \\
\hline
\end{tabular}

表 6 腎移植後の患者における生着期間別の 健康感と将来に対する不安

\begin{tabular}{l|c|c|c|c|c}
\hline & 10 年以上 & $9-5$ 年 & $4-2$ 年 & $2-1$ 年 & 計 \\
\hline & 21 例 & 40 例 & 48 例 & 18 例 & 127 例 \\
\hline 健康感 & & & & & \\
全く健康 & $81.0 \%$ & $52.5 \%$ & $41.6 \%$ & $16.7 \%$ & $48.0 \%$ \\
血液透析中より健康 & 19.0 & 47.5 & 50.0 & 61.1 & 45.7 \\
血液透析中と同じ & 0 & 0 & 4.2 & 0 & 1.5 \\
血液透析中より悪い & 0 & 0 & 0 & 16.7 & 2.4 \\
無回答 & 0 & 0 & 4.2 & 5.5 & 2.4 \\
\hline 将来に対する不安 & & & & & \\
全くなし & 4.8 & 15.0 & 6.3 & 0 & 7.9 \\
少しある & 80.9 & 70.0 & 66.7 & 61.1 & 69.3 \\
強い & 14.3 & 15.0 & 16.6 & 27.8 & 17.3 \\
わからない & 0 & 0 & 4.2 & 0 & 1.6 \\
無回答 & 0 & 0 & 6.2 & 11.1 & 3.9 \\
\hline
\end{tabular}

\section{3 ) 食生活}

腎移植後の食生活について, 健康人と全く同じものを 食べていると答えた症例は $67.0 \%$ 占め, 軽い制限を 行っているものは $27.0 \%$, 強い制限を行っているものは わずかに $4.0 \%$ に過ぎなかった。 また制限の内容では塩 分, カロリーが大部分で, 実際制限を必要とする合併症 を持っている患者は少なく, 多くは制限しているとなん となく安心だからとか, 透析中からの習慣といった理由 で制限を行っていた（図 4 ）。

4 ) 健康感と将来に対する不安

健康感に関しては約 $95.0 \%$ 患者が全く健康あるい は透析中より健康と答え, 大部分の患者が健康になった と感じていた。しかし将来に対する不安については全く ないと答えたもの $69.0 \%$, 強いと答えたもの $17.0 \%$ と, 大部分が将来に不安を感じていた。またこの健康感や不 安は, 生着期間の長さによって多少異なり, 生着期間が 長くなるにつれ, 健康感が増加し, 不安の程度も軽減す

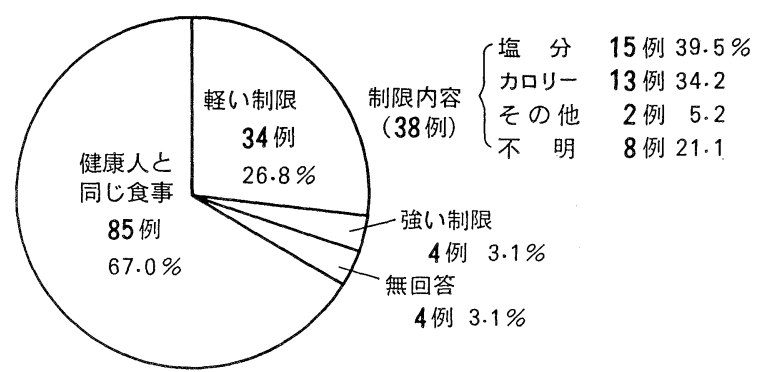

図 4 腎移植患者の食生活

\section{る傾向が認められた。}

考察

慢性腎不全などの慢性疾患に対する治療では，患者の 身体的条件だけでなく, 社会的, 経済的, 家庭的条件を 可能な限り健康時の状態に回復させ, さらにこの状態を 長期間維持することが重大な目標となろう。慢性腎不全 に対する治療のうち, 腎移植は慢性血液透析と比べ, よ り根治的であるため, 患者を取り巻く諸条件を, 健康時 の状態のかなり近いところまで回復させ得るものであ る. そのうえ, 10 年生存率 $79.0 \%$, 生着率 $54.0 \%$ という 成績や，10 年目以降では生存率 $100.0 \%$ あり，生着率 もその後 5 年目で $83.0 \%$ であっという結果は, 生着が 延長すればするほど，その後の成績は安定化することを 示している.

今回の検討で，長期間の生着を左右する因子として術 前の因子ではドナーの年齢, 術後の因子では慢性拒絶反 応があげられた.ドナーの年齢については, 50 歳を境に これ以下であった場合, 有意に良好な 10 年生着率が得ら れたが，ドナーの年齢が 50 歳以下であれば, 高血圧や動 脈硬化, その他の腎を器質的に障害する疾患も少なく, 移植された腎臓の予備能が大きいため, これがレシピ工 ントに移植された後に, よい結果を生み出していること は当然といえる．また術後の因子の慢性拒絶反応につい ては，その発症機序，治療法，予防法などはいまだ明ら かにされて扔らず，しいていえば移植後の免疫抑制剂の 投与量を，可能な限り多めに投与することが唯一の予防 法といえる.今回の検討でも移植後 10 年目の免疫抑制剂 の投与量がアザチオプリン $100 \mathrm{mg} /$ 日，プレドニン 8.8 $\mathrm{mg} /$ 日であったが，これによって特に大きな副作用を認 めておらず, 10 年以上経過した後でも慢性拒絶反応で graft loss に至った 3 例を経験していることょり，免疫 抑制剂の極端な減量や中止は避け，合併症を発症しない 最小量の投与量を維持するほうが得策と考えている。

10 年生着例における合併症では, 移植後早期における ような消化管出血, 感染症などの致命的なものは少なく, 慢性的なものがほとんどである。しかし最近 3 例の肝硬 
変を合併した症例中 2 例に大量出血を伴う食道静脈瘤が 認められた。これらはいずれも肝機能障害を合併してお り，原因として薬剤性の他，HBs キャリアーが 11 例も 存在することより, 免疫抑制下における肝炎ビールスの 活性化などの可能性が考えられる. 今後, 長期生着者の 増加とともに, 肝障害を合併する症例も増加することが 予想され, 患者管理上肝障害の取扱は, 新たな重要課題 になると考えられる。

腎移植では, より長期の生着を達成し得るかという問 題の他に, この期間中, 患者がどのような quality of life で社会的，家庭的，な生活を送れるかという問題，ある いは腎移植を受けることによって, 患者がどの程度目的 を達成し得たと自覚しているのか, という問題がある. そこで, アンケート調査をもとにこれらの問題について 検討した。

移植患者の従事している職種では, 公務員, 会社員と いった。いわゆるサラリーマンの比率は，現在の日本の 職業形態に打けるサラリーマンの比率 $74.0 \%$ と比べ幾 分低いが, 失業率, 労働時間, 休日数については, 昭和 60 年の国民生活白書に報告されている, 失業率 $2.7 \%$, 労働時間 7 時間 39 分という一般的な現状と比べて,決し て遜色はない。また血液透析では週 5 日以上稼働できた 症例は $34.3 \%$ であった, という透析研究会の報告と比べ ても, 良好な結果が得られている. 余㗇, 休日の評価に ついても $85.0 \%$ 以上が透析中よりも活発と答え, 食事内 容についても，ほぼ $70.0 \%$ の患者が健康人と同じ食事を していることは, 移植腎が機能していれば, 彼らの quality of life は健康人と全く変わりないことを示している.

さらに移植後の健康感について, 多少生着期間によっ
て差はあるものの，90.0\%以上の患者が，少なくとも透 析中よりも健康であると感じているという結果は, 治療 者であるわれわれが客観的な事実から推測して, 腎移植 を positive に評価しているだけでなく，患者自身が腎移 植を受けてよかった，と感じているためであろう。

しかし特に合併症がないにもかかわらず， 3 分の 1 の 患者が仕事を自制し, 約 4 分の 1 の患者が軽い食事制限 を行っていること, 現在の自分は健康であると感じてい

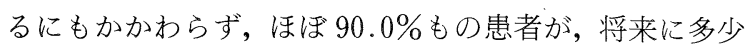
なりとも不安を感じていることは，腎移植によって慢性 腎不全が完治するものではなく，いつの日か慢性拒絶反 応によって, 再び血液透析にもどる可能性があるという ことを, 患者自身が自覚しているためではないかと考え られる。

\section{結語}

慢性腎不全に対する治療として, 腎移植は 10 年生存率 $79.0 \%$, 生着率 $54.0 \%$ と極めて成功率が高く, 長期生着 例では致命的な合併症は認めなかったが, 慢性拒絶反応 が腎移植の予後を障害する重大な問題点であった。また 移植腎が生着している場合, 患者の quality of life はほ とんど健康人と変わりなく, この面でも慢性腎不全に対 する優れた治療法であるといえる。

\section{文献}

1）東條静夫, 渡辺孝太郎：職場環境, 維持透析, 1985 年特別号：756-763，1985.

2）昭和 60 年版, 国民生活白書, 経済企画庁, 大藏省印 刷局, 1985 . 